\title{
Vulvar reconstruction should be performed using gluteal-fold perforator flap because of less morbidities and complications
}

\section{Reconstrução vulvar deve ser realizada utilizando retalho perfurante de dobra glútea devido a menos morbidades e complicações}

\author{
Masaki Fujoka, M.D., Ph.D ${ }^{1,2}$; Kenנ Hayashida, M.D2; Chikako Murakami, M.D²
}

A B S S T R A C T

The autors present a case of bilateral vulvar defects after abrasion of malignant skin neoplasm, reconstructed with a gluteal-fold perforator flap, resulting in a successful outcome.

Key words: Genitalia, female. Vulva. Perforator flap. Morbidity. Postoperative complications.

\begin{abstract}
A fasciocutaneous flap has been traditionally used for the reconstruction of vulvovaginal defects ${ }^{1}$. Soft-tissue reconstruction in the vulvar area requires thin, pliable, and tough skin. In this meaning, $\mathrm{V}-\mathrm{Y}$ fasciocutaneous gluteal flap is thought to be a good option. However, regrettably, it requires high-level morbidity at the donor site, including long scar, wide resection area, and sensory disturbance. For resolving these problems, application of the pedicled perforator flap concept has many advantages ${ }^{2-4}$.

We present a case of bilateral vulvar defects after abrasion of malignant skin neoplasm, reconstructed with a gluteal-fold perforator flap, resulting in a successful outcome.
\end{abstract}

\section{TECHNICAL ASPECTS}

A 73-year-old female was admitted to our Medical Center complaining of vulvar erosion with itching. She was diagnosed as Paget's disease of bilateral vulva on biopsy. Wide resection resulted in skin defects in bilateral valve measuring $17 \times 8 \mathrm{~cm}$ outside the vagina. Sentinel lymph node examination revealed no metastasis.

The location of cutaneous perforator vessels from the internal pudental artery was assessed preoperatively using a Doppler flowmeter. A few cutaneous perforators were recognized on the medial side of the ischial tuberosity. The flap was designed to include these points according to the size of the defect. Dissection was carried out lateral to medial in a suprafascial plane until the perforator vessel, which penetrated the fascia of ischiocavernous muscle (Fi- gure 1). The flap was rotated towards the defects and sutured. The donor site could be closed with direct suture (Figure 2).

The viability of all flaps was favorable, without infection or necrosis. The patient could walk on the next day, and was discharged one week later without sensory disturbance (Figure 3).

Six weeks later, the perforator flap revealed thin and pliable, and the appearance of reconstructed vulva was favorable (Figure 4). The patient did not complain about urination, scar contraction, and sensory disturbance.

\section{DISCUSSION}

Several musculo- and fasciocutaneous flaps are available for the resurfacing of vulvar skin defects, including rectus abdominaris or gracilis flaps, and fasciocutaneous gluteal flap which have a rich blood supply through the major arteries. Microsurgical free flap transfer is also considered for repairing vulvar soft tissue defects. However, these flaps require extended incision for flap harvest and mobilization, and especially, microvascular anastomoses have the potential disadvantage that they require considerable surgical skill and prolong the operative period ${ }^{5}$.

Perforator flaps are defined as flaps consisting of skin and/or subcutaneous fat, with a blood supply from isolated perforating vessels of a stem artery ${ }^{6}$. The most significant advantages of the perforator flap are that there is no need to sacrifice any main arteries, thus, there is minimal morbidity at the donor site. This flap is thin in

1. Clinical Professor of the Department of Plastic and Reconstructive Surgery, Nagasaki University, Nagasaki, Japan; 2. Department of Plastic and Reconstructive Surgery, Clinical Research Center, National Hospital Organization Nagasaki Medical Center, Nagasaki, Japan. 


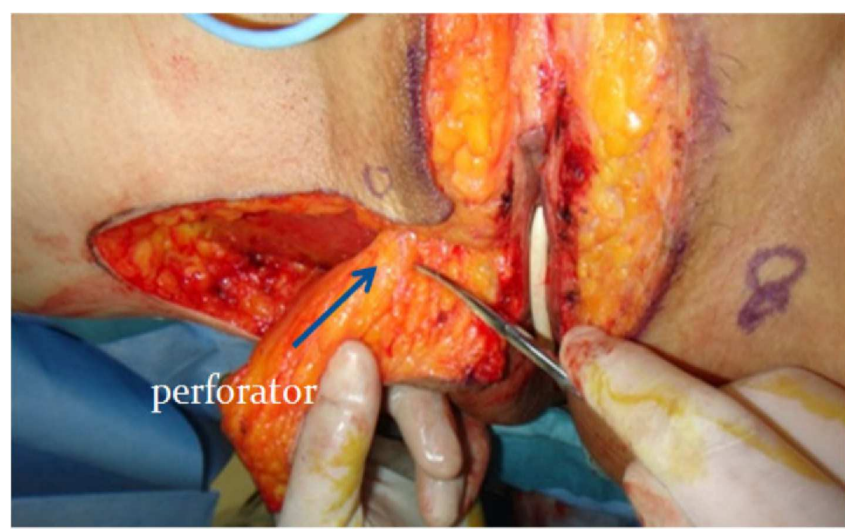

Figure 1 - An intraoperative elevation of the skin flap. A perforator vessel can be recognized (arrow).

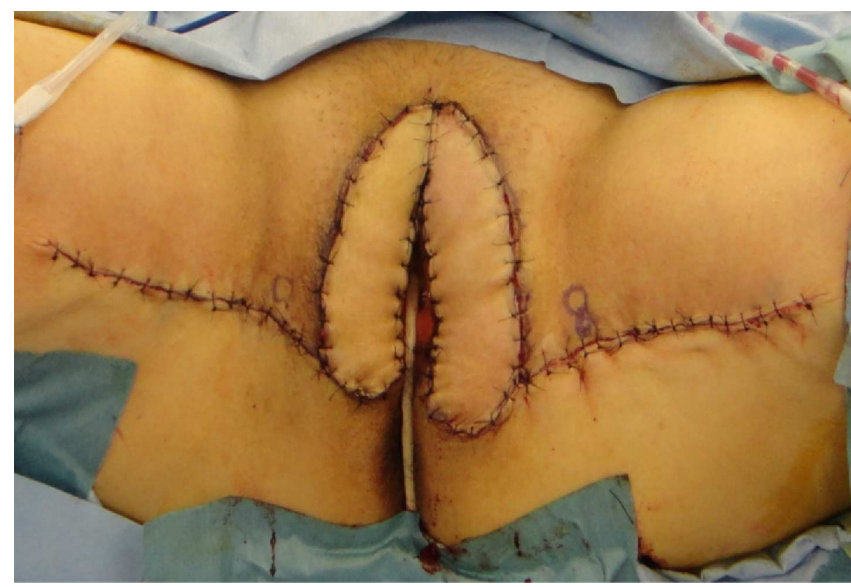

Figure 2 - The resurfacing of the vulvar wound using a glutealfold perforator flap.

comparison to the fasciocutaneous flaps, and vascularity is reliable. While elevating the fasciocutaneous flap, the long triangular incision is across the cutaneous branches of obturator and posterior thigh nerves consequently, which causes the prolonged sensory disturbance on the medial thigh and gluteal regions ${ }^{1}$. Besides, large fasciocutaneous flaps sometimes required scar revision for their contraction, and had a risk of developing seroma or hematoma after suregery ${ }^{7}$. On the other hands, dissection of perforator flaps was carried in a supra-fascial plane level, which is free from nervous disturbance. And small incision reduced intraoperative bleeding, although surgeon used usual scissors, not manage to prepare a computer-controlled bipolar diathermy system ${ }^{7}$.

The standard gluteal-fold perforator flap was harvested from the gluteal-fold for the aesthetic reason, however, many patients complained some discomfort in the sitting position due to the scars ${ }^{8}$. We did not elevate the flap from the gluteal-fold but the medial thigh, to where the pressure did not affect when the patients sat, especially, for elder patients.

An ideal flap is thought that to be a good vascularized skin paddle with the same thickness and width as the wound, which minimizes negative impacts on

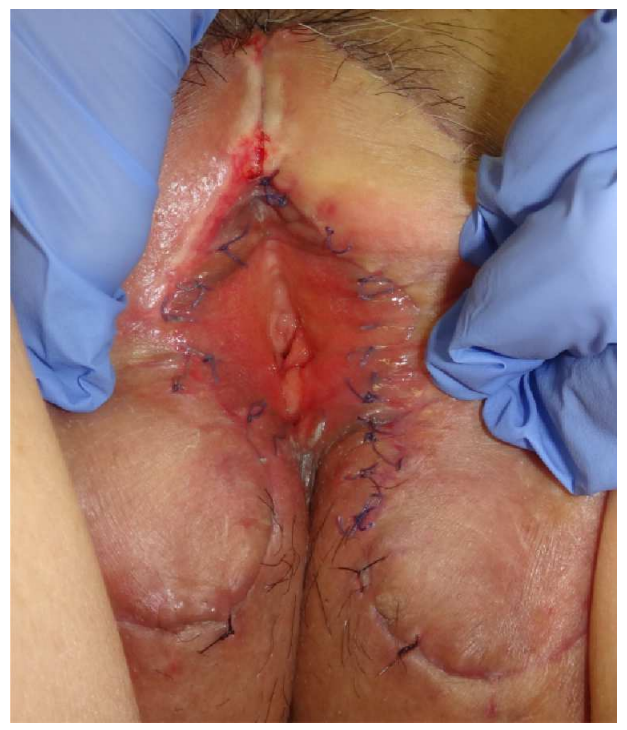

Figure 3 - The reconstructed wound two weeks after surgery.

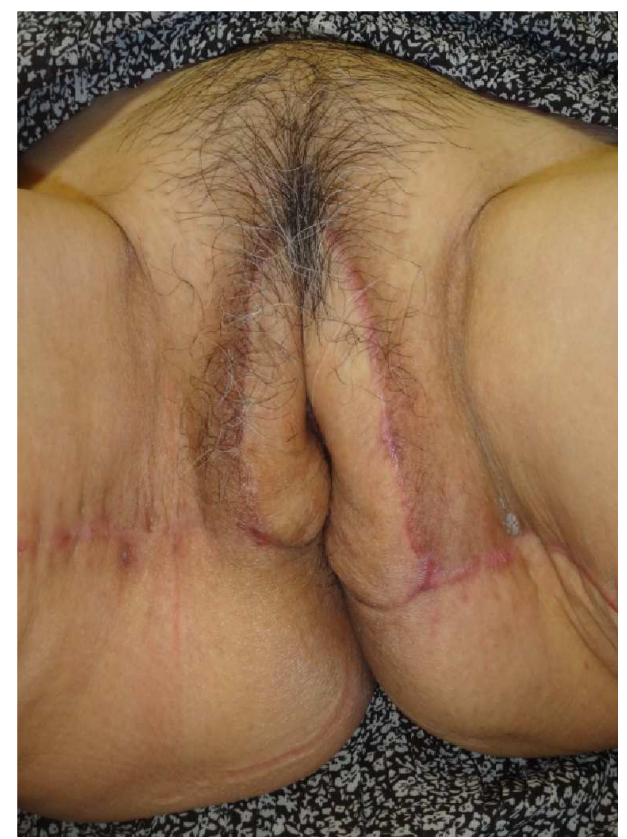

Figure 4 - View of the reconstructed vulva six weeks after surgery revealed favorable appearance without scar contraction

walking, creates a natural esthetic appearance, and requires a single-stage operation ${ }^{9}$. Gluteal-fold perforator flap fully satisfies these requirements; thus, we believe that this flap should be recommended as the first choice for vulvar resurfacing.

\section{Ethical considerations}

The procedures followed were in accordance with the ethical standards of our institutional committee on human experimentation and with the Helsinki Declaration of 1975, as revised in 1983. 


\section{R E S U M O}

Os autores apresentam um caso de defeitos vulvares bilaterais após abrasão por neoplasia cutânea maligna, reconstruído com um retalho perfurante de dobra glútea, com bom resultado.

Descritores: Genitália feminina. Vulva. Retalho perfurante. Morbidade. Complicações pós-operatórias.

\section{REFERENCES}

1. Franco D, Almeida G, Arnaut M Jr, Arbex G, Furtado Y, Franco T. Analysis of the use of fasciocutaneous flaps for immediate vulvar reconstruction. Rev Col Bras Cir. 2012;39(1):54-9.

2. Schaverien M, Saint-Cyr M. Perforators of the lower leg: analysis of perforator locations and clinical application for pedicled perforator flaps. Plast Reconstr Surg. 2008;122(1):161-70.

3. Taylor GI, Pan WR. Angiosomes of the leg: anatomic study and clinical implications. Plast Reconstr Surg. 1998;102(3):599-616; discussion 617-8.

4. Carriquiry C, Aparecida Costa M, Vasconez LO. An anatomic study of the septocutaneous vessels of the leg. Plast Reconstr Surg. 1985;76(3):354-63.

5. Serafin D, Georgiade NG, Smith DH. Comparison of free flaps with pedicled flaps for coverage of defects of the leg or foot. Plast Reconstr Surg. 1977;59(4):492-9.

6. Parrett BM, Matros E, Pribaz JJ, Orgill DP. Lower extremity trauma: trends in the management of soft-tissue reconstruction of open tibia-fibula fractures. Plast Reconstr Surg. 2006;117(4):131522; discussion 1323-4.

7. Lazzaro L, Guarneri GF, Rampino Cordaro E, Bassini D, Revesz S, Borgna $G$, et al. Vulvar reconstruction using a " $V-Y$ " fasciocutaneous gluteal flap: a valid reconstructive alternative in postoncological loss of substance. Arch Gynecol Obstet. 2010;282(5):521-7.
8. Franchelli S, Leone MS, Bruzzone M, Muggianu M, Puppo A, Gustavino C, et al. The gluteal fold fascio-cutaneous flap for reconstruction after radical excision of primary vulvar cancers. Gynecol Oncol. 2009:113(2):245-8.

9. El-Sabbagh AH. Skin perforator flaps: an algorithm for leg reconstruction. J Reconstr Microsurg. 2011;27(9):511-23.

Received on 10/10/2012

Accepted for publication 15/12/2012

Conflict of interest: none.

Source of funding: none.

How to cite this article:

Fujioka M, Hayashida K, Murakami C. Vulvar reconstruction should be performed using gluteal-fold perforator flap because of less morbidities and complications. Rev Col Bras Cir. [periódico na Internet] 2014;41(2). Disponível em URL: http://www.scielo.br/rcbc

\section{Address for correspondence:}

Fujioka Masaki

E-mail: mfujioka@nmc.hosp.go.jp 